\title{
Peripheral Nerve Function Changes Due to Hypoxia in Obstructive Sleep Apnea
}

\section{Obstrüktif Uyku Apne'de Hipoksiye Bağlı Periferal Sinir Fonksiyonu Değișiklikleri}

\author{
(D) Aynur Yılmaz Avcl, (D) Suat Avcl* \\ Başkent University Faculty of Medicine, Department of Neurology, Ankara, Turkey \\ *Başkent University Faculty of Medicine, Department of Otolaryngology, Ankara, Turkey
}

\begin{abstract}
Introduction: Chronic hypoxia is known to be one of the risk factors for peripheral neuropathy. However, the effect of intermittent hypoxia on peripheral nerves is not fully understood. This study evaluated the relation between intermittent hypoxia and peripheral nerve function in Obstructive Sleep Apnea (OSA) patients.

Materials and Methods: In this retrospective study, 86 patients who underwent polysomnography (PSG) and electroneuromyography were enrolled. Participants with diseases affecting peripheral nerves and lung function were excluded from the study. Hypoxia parameters were obtained from the PSG study. Lower extremity motor and sensory nerve conduction studies of all patients were evaluated.

Results: In patients with OSA, peroneal nerve distal motor latency and sural sensory nerve action potential amplitude was low and velocity was significantly slower than controls $(p<0.001, p<0.04, p<0.001$, respectively). After adjustment for age and body mass index, the results remained significantly $(p<0.001, p<0.01, p<0.001$, respectively). The nerve conduction results were significantly correlated with the hypoxia parameters. After adjustment for confounding factors, logistic regression analyses revealed that hypoxia parameters were independently associated with nerve conduction results.

Conclusion: OSA and intermittent hypoxia may affect both motor and sensory nerve conduction, which suggests that subclinical sensorimotor peripheral neuropathy is associated with OSA. The related intermittent hypoxia and OSA may be a cause of axonal and demyelinating neuropathies.
\end{abstract}

Keywords: Sleep Apnea syndrome, sleep-disordered breathing, electromyography, hypoxia, neuropathy
Öz

Amaç: Periferik nöropati için risk faktörlerinden birinin kronik hipoksi olduğu bilinmektedir. Bununla birlikte, aralıklı hipoksinin periferal sinirler üzerindeki etkisi tam olarak anlaşılamamıştır. Bu çalışmada Obstrüktif Uyku Apnesi (OSA) hastalarında aralıklı hipoksi ve periferik sinir fonksiyonu arasındaki ilişki değerlendirildi.

Gereç ve Yöntem: Bu retrospektif çalışmaya polisomnografi (PSG) ve elektronöromiyografi uygulanmış 86 hasta alındı. Periferik sinirleri ve akciğer fonksiyonlarını etkileyen hastalıkları olan katılımcılar çalışma dışı bırakıldı. Hipoksi parametreleri PSG çalışmasından elde edildi. Tüm hastaların alt ekstremite motor ve duyu siniri iletim çalışmaları değerlendirildi.

Bulgular: OSA'lı hastalarda kontrollere göre peroneal sinir distal motor latansı ve sural duyusal sinir aksiyon potansiyeli amplitüdü düşük ve hızı anlamlı olarak yavaştı $(p<0,001, p<0,04, p<0,001$, sırasıyla). Yaş ve vücut kitle indeksi için ayarlama yapıldıktan sonra, sonuçlar anlamlı kaldı ( $p<0,001, p<0,01, p<0,001$, sırasıyla). Sinir iletim sonuçları hipoksi parametreleri ile anlamlı olarak korele idi. Karıștıııcı faktörler ayarlandıktan sonra, lojistik regresyon analizleri, hipoksi parametrelerinin sinir iletimi sonuçlarıyla bağımsız olarak ilişkili olduğunu gösterdi.

Sonuç: OSA ve aralıkı hipoksi, hem motor hem de duyusal sinir iletimini etkileyebilmekte, bu da subklinik sensorimotor periferik nöropatinin OSA ile ilişkili olduğunu düşündürmektedir. OSA ve ilgili aralıkı hipoksi, aksonal ve demiyelinizan nöropatinin bir nedeni olabilir.

Anahtar Kelimeler: Uyku Apne sendromu, uykuda solunum bozukluğu, elektromiyografi, hipoksi, nöropati

\section{Introduction}

Obstructive Sleep Apnea (OSA) is common in the general population. Recurrent episodes of the collabing upper airway during sleep, and the resulting intermittent hypoxia, are important features of OSA. The reported estimated prevalence of OSA in adults is 3 7\% for males and $2 \sim 5 \%$ for females (1). During OSA, intermittent cycles of falling oxygen saturation and reoxygenation, and rises in pharyngeal resistance and esophageal pressure, microarousal, and hypercapnia occur.

Address for Correspondence/Yazışma Adresi: Aynur Yılmaz Avcı MD, Başkent University Faculty of Medicine, Department of Neurology, Ankara, Turkey Phone: +90242510 2525 E-mail: aynuryilmazavci@gmail.com ORCID-ID: orcid.org/0000-0001-9004-9382 Received/Geliş Tarihi: 23.12.2018 Accepted/Kabul Tarihi: 15.05.2019

${ }^{\circ}$ Copyright 2018 by Turkish Sleep Medicine Society / Journal of Turkish Sleep Medicine published by Galenos Publishing House. 
Avcl and Avcl.

Neuropathy in Obstructive Sleep Apnea

The chronic cycles of desaturation-reoxygenation during intermittent hypoxia induce oxidative stress, producing an inflammatory response and reactive oxygen species, which are responsible for OSA-related complications, such as metabolic, neurocognitive, and cardiovascular disorders $(2,3)$.

In patients with chronic obstructive pulmonary disease (COPD) neurophysiological changes have been found in in $90 \%$ of the cases. The reported high incidence is thought to be related to hypoxia $(4,5)$. Chronic hypoxia induces peripheral polyneuropathy and this form of nerve damage is associated with the severity and duration of hypoxia (6-8). Prevalence of polyneuropathy due to chronic hypoxia have been reported in a similar range of $28 \%$ to $70 \%$ in patients with OSA and COPD (5,9-11).

Previous studies have reported that peripheral nerve sensory amplitudes are impaired in OSA patients, but the relationship with hypoxemia has not been fully elucidated $(9,12,13)$. We hypothesized that patients with severe OSA and hypoxia show significantly impaired peripheral nerve conduction compared to controls. In this study, patients were subgrouped according to hypoxia parameters and the apnea-hypopnea index (AHI). Following this we determined whether the severities of OSA and hypoxia were associated with lower extremity motor and sensory nerve conduction abnormalities.

\section{Materials and Methods}

\section{Patient's Characteristics}

This retrospective study was performed at the neurology outpatient clinic of university hospital. Subjects who underwent polysomnography (PSG) at our sleep disturbance center (accredited by the Turkish Sleep Association) and who underwent nerve conduction studies (NCSs) between October 2008 and January 2018 were selected. In the patients' medical histories, the presence of vascular risk factors and systemic diseases were recorded. Exclusion criteria were patients aged under 18 years, presence of any radiculopathy, traumatic neuropathy, Central Sleep Apnea syndrome, narcolepsy, COPD, bronchial asthma, chronic alcohol intake, hypertension, coronary heart disease, hyperlipidemia, diabetes mellitus, goiter, chronic renal failure, liver failure, malignancy, or use of neurotoxic drugs.

After applying the exclusion criteria, 86 of 237 selected patients were included. Using the $\mathrm{AHI}$, the participants were divided into a control group (AHI $\leq 5)(n=40)$ and OSA group $(A H I>5)$ $(n=46)$. Age, sex, body mass index (BMI), Epworth Sleepiness Scale were measured. Hypoxia parameters including the lowest oxygen saturation ( $\min \mathrm{SaO}_{2}$ ), total sleep duration with oxygen saturation $<90 \%\left(\mathrm{ST}_{90}\right)$, percentage of cumulative time with oxygen saturation $<90 \%\left(\mathrm{CT}_{90}\right), 3 \%$ oxygen desaturation index (ODI), and sleep time were calculated and recorded from the patients' PSG records. The participants were further subdivided according to $\mathrm{ST}_{90^{\prime}} \mathrm{CT}_{90^{\prime}}$ min $\mathrm{SaO}_{2^{\prime}}$ and ODI.

This study was exempted from the requirement for ethics committee approval from the institutional review board of our university due to its retrospective nature.

\section{Polysomnography}

All participants underwent PSG using a computerized PSG device in the sleep laboratory (E series, 44 channels; Compumedics, Victoria, NSW, Australia). The following parameters were documented during the PSG study (16 channels): four-channel electroencephalogram, electrooculogram, submental and leg electromyogram, electrocardiogram, nasal airflow using a nasal pressure cannula, airflow at the nose and mouth (thermistors), chest and abdominal respiratory movements, oxygen saturation (pulse oximetry), snoring microphone, and body position. All studies were interpreted by a sleep specialist (pulmonologist) who was blinded to the participants' characteristics. Apnea, hypopneaand sleep staging were defined and performed according to standards of the American Academy of Sleep Medicine criteria (14). The $\mathrm{ST}_{90}$ was recorded in minutes, and min $\mathrm{SaO}_{2}$ and $\mathrm{CT}_{90}$ were recorded as percentages. The min $\mathrm{SaO}_{2}$ value was the lowest oxygen saturation during sleep.

\section{Nerve Conduction Studies}

NCSs of bilateral tibial, peroneal, and sural nerves were performed using an electromyography device (Neuropack M1 MEB 2002; Nihon Kohden, Tokyo, Japan). Standardized techniques and procedures were used as described in the guidelines of electrodynamic medicine (15). Filter settings were $3 \mathrm{~Hz}-10 \mathrm{kHz}$ for the motor NCSs and $20 \mathrm{~Hz}-2 \mathrm{kHz}$ for the sensory NCSs. During the testing procedures, the room temperature was maintained at an average of $25^{\circ} \mathrm{C}$ and skin temperature was maintained at $>33^{\circ} \mathrm{C}$ in all participants.

\section{Statistical Analysis}

The statistical data were evaluated using IBM SPSS Statistics for Windows (ver. 20.0; IBM Corp, Armonk, NY, USA). To test the homogeneity of variances, which is a prerequisite of parametric tests, Levene's test was used. The assumption of normality was tested via the Shapiro-Wilk test. To compare differences between the characteristics of patients with OSA and controls, the Student's t-test was used when the parametric test prerequisites were met, and the Mann-Whitney $U$ test was used when such prerequisites were not met. The chi-square test was used to determine the relationships between two discrete variables. Values were determined through the Monte Carlo simulation method when the expected sources were less than $20 \%$ to include such sources in analyses. Age and BMI were determined as covariates (to be excluded), and groups were compared by a covariance analysis (Table 1). The relationship between two continuous variables was assessed by Pearson's correlation analyses and Spearmans correlation analyses when the parametric test prerequisites were not met (Table 2). Binary logistic regression analyses were used to reveal the model for the relationship between the independent and dependent variables (Table 3). A p value $<0.05$ was set for level of significance.

\section{Results}

Characteristics of the subjects with OSA and the controls are described in Table 1. Significant differences in age, sex, $\mathrm{BMI}$, the $\mathrm{AHI}$, and the hypoxia parameters were observed among both groups (Table 1). In OSA subjects, peroneal nerve distal motor latency was prolonged and sural Sensory nerve action potential (SNAP) amplitude and velocity were significantly decreased (Table 1). After adjusting for age and $\mathrm{BMI}$, the differences in peroneal nerve motor latency, sural SNAP amplitude, and sural nerve conduction velocity (NCV) of the two groups remained significant (Table 1). Univariate analyses revealed a significant mild to moderate correlation 
Avcl and Avcl.

Neuropathy in Obstructive Sleep Apnea

\begin{tabular}{|c|c|c|c|c|c|}
\hline & & Control & Obstructive Sleep Apnea & \multirow{2}{*}{$\mathrm{p}$} & Adjust BMI and Age" \\
\hline & & $\mathrm{n}=40$ & $\mathrm{n}=46$ & & $\mathbf{p}$ \\
\hline \multicolumn{2}{|c|}{ Age (years) } & $44.4 \pm 13.9$ & $54.7 \pm 12.4$ & $0.001 \dagger$ & - \\
\hline \multirow{2}{*}{ Sex } & Female & $22(55 \%)$ & $12(26.1 \%)$ & \multirow{2}{*}{$0.006 \S$} & \multirow{2}{*}{-} \\
\hline & Male & $18(45 \%)$ & $34(73.9 \%)$ & & \\
\hline \multicolumn{2}{|c|}{ Epworth Sleepiness Scale } & $6.7 \pm 6.3$ & $10.8 \pm 0.5$ & $0.001^{\ddagger}$ & 0.001 \\
\hline \multicolumn{2}{|c|}{ Body mass index $\left(\mathrm{kg} / \mathrm{m}^{2}\right)$} & $25.8 \pm 3.4$ & $32.3 \pm 5.3$ & $0.001^{\ddagger}$ & - \\
\hline \multicolumn{2}{|c|}{ Apnea-hypopnea index (events/h) } & $1.5 \pm 1.3$ & $23.3 \pm 20.6$ & $0.001 \dagger$ & 0.001 \\
\hline \multicolumn{2}{|c|}{ Total sleep time (min) } & $447.1 \pm 22.9$ & $440.6 \pm 40.5$ & NS & NS \\
\hline \multicolumn{2}{|c|}{ Oxygen desaturation index (\%) } & $3.1 \pm 1.4$ & $4.9 \pm 1.6$ & $0.001^{\ddagger}$ & 0.001 \\
\hline \multicolumn{2}{|c|}{$\mathrm{ST}_{90}(\min )$} & $1.3 \pm 3.3$ & $23.3 \pm 47.5$ & $0.001^{\ddagger}$ & 0.001 \\
\hline \multicolumn{2}{|c|}{$\mathrm{CT}_{90}(\%)$} & $0.3 \pm 0.7$ & $5.6 \pm 12.2$ & $0.01^{\ddagger}$ & 0.01 \\
\hline \multicolumn{2}{|c|}{ Minimum oxygen saturation (\%) } & $90.7 \pm 4.7$ & $81.2 \pm 7.8$ & $0.001^{\ddagger}$ & 0.001 \\
\hline \multicolumn{2}{|c|}{ Tibial motor nerve latency (ms) } & $4.2 \pm 0.7$ & $4.3 \pm 0.91$ & $0.001^{\ddagger}$ & 0.001 \\
\hline \multicolumn{2}{|c|}{ Tibial CMAP amplitude (mV) } & $15.4 \pm 6.2$ & $11.8 \pm 4.5$ & $0.040^{\ddagger}$ & 0.01 \\
\hline \multicolumn{2}{|c|}{ Tibial motor nerve velocity $(\mathrm{m} / \mathrm{s})$} & $48.1 \pm 4.03$ & $45.1 \pm 8.3$ & NS‡ & NS \\
\hline \multicolumn{2}{|c|}{ Peroneal motor nerve latency (ms) } & $3.9 \pm 0.5$ & $4.2 \pm 0.7$ & $0.001^{\ddagger}$ & 0.001 \\
\hline \multicolumn{2}{|c|}{ Peroneal CMAP amplitude (mV) } & $10.3 \pm 4.3$ & $6.9 \pm 2.9$ & NS & NS \\
\hline \multicolumn{2}{|c|}{ Peroneal motor nerve velocity $(\mathrm{m} / \mathrm{s})$} & $50.9 \pm 4.9$ & $49.3 \pm 5.4$ & NS & NS \\
\hline \multicolumn{2}{|c|}{ Sural nerve latency (ms) } & $2.3 \pm 0.3$ & $2.2 \pm 0.3$ & $0.01^{\ddagger}$ & 0.01 \\
\hline \multicolumn{2}{|c|}{ Sural SNAP amplitude (mV) } & $19.5 \pm 9.04$ & $14.2 \pm 8.3$ & $0.04^{\ddagger}$ & 0.01 \\
\hline \multicolumn{2}{|c|}{ Sural nerve velocity $(\mathrm{m} / \mathrm{s})$} & $55.01 \pm 6.2$ & $50.6 \pm 12.2$ & $0.001 \dagger$ & 0.001 \\
\hline \multicolumn{6}{|c|}{$\begin{array}{l}\text { CMAP: Compound muscle action potential, } \mathrm{CT}_{90} \text { : Percentage of cumulative sleep time with oxygen saturation }<90 \% \text {, SNAP: Sensory nerve action potential, } \\
\mathrm{ST}_{90} \text { : Total sleep time with oxygen saturation }<90 \%\end{array}$} \\
\hline \multicolumn{6}{|c|}{ 'NS: nNt significant $(p>0.05)$} \\
\hline \multicolumn{6}{|c|}{ †Mann-Whitney U Test } \\
\hline \multicolumn{6}{|c|}{ ¥Student's t-test } \\
\hline \multicolumn{6}{|c|}{$\S$ Fisher Exact chi-square test } \\
\hline
\end{tabular}

\begin{tabular}{|c|c|c|c|c|c|c|c|c|c|c|}
\hline & & $\begin{array}{l}\text { Tibial } \\
\text { motor } \\
\text { latency }\end{array}$ & $\begin{array}{l}\text { Tibial CMAP } \\
\text { amplitude }\end{array}$ & \begin{tabular}{|l|} 
Tibial \\
motor \\
velocity
\end{tabular} & $\begin{array}{l}\text { Peroneal } \\
\text { motor } \\
\text { latency }\end{array}$ & $\begin{array}{l}\text { Peroneal } \\
\text { CMAP } \\
\text { amplitude }\end{array}$ & $\begin{array}{l}\text { Peroneal } \\
\text { motor } \\
\text { velocity }\end{array}$ & $\begin{array}{l}\text { Sural } \\
\text { sensory } \\
\text { latency }\end{array}$ & $\begin{array}{l}\text { Sural SNAP } \\
\text { amplitude }\end{array}$ & $\begin{array}{l}\text { Sural } \\
\text { sensory } \\
\text { velocity }\end{array}$ \\
\hline \multirow{2}{*}{ ODI } & $r$ & 0.290 & -0.468 & -0.328 & 0.329 & -0.421 & -0.221 & 0.101 & -0.247 & -0.365 \\
\hline & $p$ & $0.007^{\ddagger}$ & $0.000 \dagger$ & $0.002^{\ddagger}$ & $0.002^{\ddagger}$ & $0.000 \dagger$ & $0.041^{\ddagger}$ & NS" & $0.022^{\ddagger}$ & $0.001 \dagger$ \\
\hline \multirow{2}{*}{$\mathrm{ST}_{90}$} & $r$ & 0.081 & -0.183 & -0.283 & 0.105 & -0.400 & -0.078 & -0.112 & -0.236 & -0.298 \\
\hline & $\mathrm{p}$ & NS & NS & $0.008^{\ddagger}$ & NS & $0.000^{\ddagger}$ & NS & NS‡ & $0.029^{\ddagger}$ & $0.005^{\ddagger}$ \\
\hline \multirow{2}{*}{$\mathrm{CT}_{90}$} & $r$ & 0.076 & -0.159 & -0.272 & 0.072 & -0.378 & -0.074 & -0.121 & -0.215 & -0.269 \\
\hline & $\mathrm{p}$ & $N S^{\ddagger}$ & NS & $0.011^{*}$ & $N S^{\ddagger}$ & $0.000^{\ddagger}$ & NSt & $N S^{\ddagger}$ & $0.046^{\ddagger}$ & $0.012^{\ddagger}$ \\
\hline \multirow{2}{*}{$\min \mathrm{O}_{2}$} & $r$ & -0.144 & 0.339 & 0.324 & -0.255 & 0.467 & 0.120 & 0.085 & 0.203 & 0.286 \\
\hline & $\mathrm{p}$ & $N S^{\ddagger}$ & $0.001 \dagger$ & $0.002^{\ddagger}$ & $0.018^{\ddagger}$ & $0.000 \dagger$ & NSt & NSt & NS† & $0.008^{\ddagger}$ \\
\hline \multicolumn{11}{|c|}{$\begin{array}{l}\text { CMAP: Compound muscle action potential, } \mathrm{CT}_{90} \text { : Percentage of cumulative sleep time with oxygen saturation }<90 \% \text {, min } \mathrm{O}_{2} \text { : Lowest oxygen saturation, } \\
\text { ODI: Oxygen desaturation index, SNAP: Sensory nerve action potential, } \mathrm{ST}_{90} \text { : Total sleep time with oxygen saturation }<90 \%\end{array}$} \\
\hline \multicolumn{11}{|c|}{ †NS: Not significant $(p>0.05)(n=86)$} \\
\hline \multicolumn{11}{|c|}{$†$ Pearson correlation } \\
\hline \multicolumn{11}{|c|}{ *Spearman correlation } \\
\hline
\end{tabular}


Avcl and Avcl.

Neuropathy in Obstructive Sleep Apnea

\begin{tabular}{|c|c|c|c|c|c|c|}
\hline \multirow{2}{*}{\multicolumn{2}{|c|}{ Model }} & \multicolumn{2}{|c|}{ Unstandardized coefficients } & \multirow{3}{*}{$\begin{array}{l}\text { Standardized coefficients } \\
\text { Beta } \\
-0.293\end{array}$} & \multirow{3}{*}{$\begin{array}{l}\mathbf{t} \\
-2,766\end{array}$} & \multirow{3}{*}{$\begin{array}{l}\mathbf{p} \\
0.007\end{array}$} \\
\hline & & \multirow{2}{*}{\begin{tabular}{|l|} 
B \\
-2.655
\end{tabular}} & \multirow{2}{*}{$\begin{array}{l}\text { Standard error } \\
0.960\end{array}$} & & & \\
\hline \multirow{3}{*}{$\mathrm{ST}_{90}(\min )$} & Peroneal CMAP amplitude (mV) & & & & & \\
\hline & Sural sensory latency (ms) & -41.721 & 18.491 & -0.343 & -2.256 & 0.027 \\
\hline & Sural sensory velocity $(\mathrm{m} / \mathrm{s})$ & -1.880 & 0.917 & -0.319 & -2.050 & 0.044 \\
\hline \multirow{5}{*}{$\mathrm{CT}_{90}(\%)$} & Tibial motor velocity $(\mathrm{m} / \mathrm{s})$ & $-0,423$ & 0.226 & -0.211 & -1.868 & NS \\
\hline & Peroneal motor latency (ms) & -2.764 & 1.638 & -0.184 & -1.688 & NS \\
\hline & Peroneal CMAP amplitude (mV) & -0.591 & 0.256 & -0.255 & -2.306 & 0.024 \\
\hline & Sural sensory latency (ms) & -14.087 & 5.016 & -0.453 & -2.808 & 0.006 \\
\hline & Sural sensory velocity $(\mathrm{m} / \mathrm{s})$ & -0.533 & 0.241 & -0.353 & -2.210 & 0.030 \\
\hline \multirow{4}{*}{$\min \mathrm{SaO}_{2}(\%)$} & Tibial motor velocity (ms) & 0.404 & 0.187 & 0.231 & 2.161 & 0.034 \\
\hline & Peroneal CMAP amplitude (mV) & 0.643 & 0.213 & 0.319 & 3.016 & 0.003 \\
\hline & Sural sensory latency (ms) & 9.340 & 4.081 & 0.345 & 2.288 & 0.025 \\
\hline & Sural sensory velocity $(\mathrm{m} / \mathrm{s})$ & 0.332 & 0.196 & 0.252 & 1.695 & NS \\
\hline \multirow{3}{*}{ ODI (\%) } & Tibial CMAP amplitude (mV) & -0.094 & 0.032 & -0.301 & -2.910 & 0.005 \\
\hline & Peroneal motor latency (ms) & 0.486 & 0.280 & 0.174 & 1.737 & NS \\
\hline & Peroneal CMAP amplitude (mV) & -0.097 & 0.046 & -0.224 & -2.111 & 0.038 \\
\hline \multicolumn{7}{|c|}{$\begin{array}{l}\mathrm{CT}_{90} \text { : Percentage of cumulative sleep time with oxygen saturation }<90 \% \text {, } \min _{\mathrm{SaO}} \text { : Lowest oxygen saturation, ODI: Oxygen desaturation index, } \mathrm{ST}_{90} \text { : Total sleep time } \\
\text { with oxygen saturation }<90 \% \text {, CMAP: Compound muscle action potantial }\end{array}$} \\
\hline \multicolumn{7}{|c|}{${ }^{\dagger} N S$ : Not significant $(p>0.05)$} \\
\hline \multicolumn{7}{|c|}{${ }^{*}$ Data are correlation coefficients and $95 \%$} \\
\hline
\end{tabular}

between the NCS results and the hypoxia parameters (Table 2). After adjusting for confounding factors, multiple logistic regression analyses revealed that prolonged sural sensory latency [odds ratio OR: $0.018,95 \%$ confidence interval $(\mathrm{Cl})$ : $0.001-0.550, p=0.021]$ and slowing of sural conduction velocity (OR: $0.816,95 \% \mathrm{Cl}: 0.982-0.031, \mathrm{p}=0.031$ ) were independently associated with OSA. Furthermore, logistic regression analyses revealed that the $\mathrm{ST}_{90^{\prime}} \mathrm{CT}_{90^{\prime}}$ min $\mathrm{SaO}_{2}$, and ODI were independently affecting the NCSs (Table 3).

\section{Discussion}

This study suggested that OSA and intermittent hypoxia have significant effects on motor and sensory peripheric nerve function. The peroneal nerve distal latency was prolonged, sural SNAP amplitude reduced, and sural nerve velocity decreased in the OSA group (Table 1). NCSs results showed a significant correlation with the hypoxia (Table 2 ). The hypoxia parameters were independent factors associated with nerve conduction abnormalities (Table 3). This subclinical peripheral neuropathy is therefore related to severe OSA and intermittent hypoxia seems to cause axonal and demyelinating neuropathy.

Our study shows a relationship among axonal neuropathy, hypoxia parameters and nerve conduction in OSA patients, which is consistent with previous reports $(9,10,13)$. These studies also reported that subjects with severe OSA, $\min \mathrm{SaO}_{2} \leq 80 \%$, and $\mathrm{ST}_{90}$ have lower amplitude for sensory and mixed nerve action potentials, and that sural nerve velocity is slower in OSA patients $(8,9)$. Similar to our study, hypoxia-associated axonal degeneration and less frequent demyelination were reported in COPD subjects in another study (16). These pathophysiological changes in nerve damage are more functional than structural because sleep apnea treatment revealed that the impaired nerve function was partially reversible $(10,17)$.

In contrast to our study, Evlice et al. (12) described a decrease in tibial CMAP amplitude and slower tibial NCV in the OSA group, but they found no correlation among the severity of OSA, min $\mathrm{SaO}_{2}$, and neuropathy. The patients with OSA were older compared to our study and the authors only used the min $\mathrm{SaO}_{2}$ saturation as a hypoxia parameter (12).

The etiology of hypoxia-related diseases is complex. The episodic upper airway obstruction in patients with OSA results in hypoxia and hypercapnia. Hypoxia causes oxidative stress, sympathetic activation, metabolic dysfunction, systemic inflammation, endothelial dysfunction, and arterial disease together with pathological changes in morphology $(2,18,19)$. Electrophysiological abnormalities are reported in approximately $95 \%$ of subjects with COPD associated with hypoxia $(4,5)$. The pathophysiology of the nerve conduction abnormalities in patients with OSA is not exactly known. There are several possible explanations for the association between neuropathy of the peripheral nerve and OSA. Oxidative stress plays an important role in hypoxia-induced neuropathy. Endoneurial 
hypoxia causes increased intercapillary distance resulting from nerve edema $(7,20)$. The nerve capillary basement membrane thickens and endothelial cell hyperplasia and hypertrophy occur in hypoxic neuropathy. These microvascular angiopathic changes inhibit transport of nutrients and oxygen, altering nerve function and structure and predispose the patient to narrowing of the capillary lumen and vascular occlusion $(6,21)$. In addition, the high-frequency intermittent hypoxia associated with OSA is characterized by a reoxygenation and hypoxemia cycle similar to ischemia-reperfusion injury and generates oxidative stress and reactive oxygen species. During severe hypoxemia, the ischemia and reperfusion sequence leads to the development of tissue acidosis, while intracellular sodium and calcium accumulation lead to sarcolemma damage $(22,23)$. Furthermore, an excitotoxicity mechanism mediated by excitatory amino acids has been reported in hypoxic central nervous system damage. This excitotoxicity is thought to be related to oxidative stress-induced energy metabolism, leading to neurodegeneration $(24,25)$. Last, hypoxic nerves develop resistance to ischemic conduction block (RIBC) due to reduced energy requirement and an increased efficiency of anaerobic glycolysis (26). RIBC is thought to be partially reversible with treatment (10). Chronic severe intermittent hypoxia exposure often results in RIBC, leading to axonopathies. RIBC is a result of an adaptive mechanism that depends on a critical threshold of nocturnal oxygen desaturation and microvascular disorders $(10,26)$. The combination of changes in OSA associated hypoxia results in a high susceptibility to peripheral nerve injury.

The strength of our study is that we have excluded patients with risk factors that cause neuropathy and evaluated detailed hypoxia parameters. Nevertheless, there are limitations of this work included its retrospective design and single-center analysis. Hyperinsulinemia combined with insulin resistance states, such as obesity, may contribute to nerve dysfunction (6). In our study, we did not exclude subjects with BMI $\geq 30 \mathrm{~kg} /$ $\mathrm{m}^{2}$. But when we adjusted for age and BMI, the results were persistent. Although our study excluded subjects with diabetes, hyperinsulinemia and insulin resistance were not evaluated. Another limitation is that we did not include upper extremity NCS, only lower extremity NCS.

In conclusion, our study revealed that OSA and associated hypoxia affect both motor and sensory nerve conduction, revealing that subclinical peripheral neuropathy is related to OSA. The severity of OSA and severe intermittent hypoxia may cause axonal and demyelinating neuropathy. Future studies comparing the results of our nerve conduction study with oxidative stress and hypercapnia are necessary to provide better insight into the pathophysiology of neuropathy in OSA. These studies should be multicentered, and prospective with a larger OSA patient population.

\section{Acknowledgments}

The author thanks Mustafa Agah Tekindal for performing the statistical analysis (PhD, Associate Professor, Facult of Medicine, Department of Biostatistics), Hakan Gökahmetoğlu (technician) for helping collecting data, Hüseyin Lakadamyalı for evaluating the all the polysomnographs (from the department of Pulmonology, Associate Professor), and Hatice Gönüllü (M.D. and MSc) for English editing.

\section{Ethics}

Ethics Committee Approval: This study was deemed to be exempt from the requirement for informed consent by the Institutional Review Board of University due to its retrospective design. All procedures performed in studies involving human participants were in accordance with the ethical standards of the institutional and/or national research committee and with the 1964 Helsinki Declaration and its later amendments or comparable ethical standards.

Informed Consent: Oral informed consent was taken from all the participants.

Peer-review: Internally peer-reviewed.

\section{Authorship Contributions}

Desing: A.Y.A, S.A., Data Collection or Processing: A.Y.A., S.A., Analysis or Interpretation: A.Y.A., Literature Search: A.Y.A., Writing: A.Y.A.

Conflict of Interest: The authors declare that they have no conflict of interest.

Financial Disclosure: The authors declare that this study received no financial support.

\section{References}

1. Punjabi NM. The epidemiology of adult obstructive sleep apnea. Proc Am ThoracSoc 2008;5:136-43.

2. Sforza E, Roche F. Chronic intermittent hypoxia and obstructive sleep apnea: An experimental and clinical approach. Hypoxia 2016;4:99-108.

3. Beaudin AE, Waltz X, Hanly PJ, Poulin MJ. Impact of obstructive sleep apnoea and intermittent hypoxia on cardiovascular and cerebrovascular regulation. Exp Physiol 2017;102:743-63.

4. Kayacan O, Beder S, Deda G, Karnak D. Neurophysiological changes in COPD patients with chronic respiratory insufficiency. Acta Neurol Belg 2001;101:160-5.

5. Valli G, Barbieri S, Sergi P, Fayoumi Z, Berardinelli P. Evidence of motor neuron involvement in chronic respiratory insufficiency. J Neurol Neurosurg Psychiatr 1984;47:1117-21.

6. Malik RA, Masson EA, Sharma AK, Lye RH, Ah-See AK, Compton AM, Tomlinson DR, Hanley SP, Boulton AJM. Hypoxic neuropathy: Relevance to human diabetic neuropathy. Diabetologia 1990;33:311-8.

7. Low PA, Nukada H, Schmelzer JD, Tuck RR, Dyck PJ. Endoneurial oxygen tension and radial topography in nerve edema. Brain Res 1985;341:147-54.

8. Tapan ÖO, Tapan U, Kilıç US. Obstruktf uyku apne sendromlu hastalarda hipoksinin göz üzerine etkileri. JTSM 2018;5:62-6.

9. Ludemann $P$, Dziewas $R$, Soros $P$, Happe $S$, Frese A. Axonal polyneuropathy in obstructive sleep apnoea. I NeurolNeurosurg Psychiatry 2001;70:685-7.

10. Mayer P, Dematteis M, Pepin JL, Wuyam B, Veale D, Vila A, Levy P. Peripheral neuropathy in sleep apnea. Am J Respir Crit Care Med 1999;159:213-9.

11. Agrawal D, Vohra R, Gupta P, Sood S. Subclinical peripheral neuropathy in stable middle-aged patients with chronic obstructive pulmonary disease. Singapore Med 2007;48:887-94.

12. Evlice A, Ugurel B, Baklan B, Oztura I. Neuropathy and dysautonomia in patients with obstructive sleep apnea syndrome. Arch Neuropsychiatr 2015;52:24-8. 
Avcı and Avcl.

Neuropathy in Obstructive Sleep Apnea

13. Mihalji M, Lusic L, Dogas Z. The AASM manual for the scoring of sleep and associated events: Rules, Reduced evoked motor and sensory potential amplitudes in obstructive sleep apnea patients. J Sleep Res 2016;25:287-95.

14. Berry RB, Brooks R, Gamaldo CE, Harding SM, Lloyd RM, Marcus CL, Vaughn BV. American Academy of Sleep terminology and technical specifications, version 2.2. Darien IL: American Academy of sleep medicine. J Clin Sleep Med 2015;11:1253-4.

15. American Association of Electrodiagnostic Medicine. Guidelines in electrodiagnostic medicine. Muscle Nerve 1992;15:229-53.

16. Vila A, Reymond F, Paramelle B, Stoebner P, Quvrard-Hernandez AM, Muller P, Pollak P. Neuropathies and chronic respiratory insufficiency: Electrophysiologic study. Rev Electroencephalgr Neurophysiol Clin 1986;15:331-40.

17. Dziewas $R$, Schilling $M$, Engel $P$, Boentert $M$, Hor $H$, Okegwo $A$, Ludemann P, Ringelstein EB, Young P. Treatment for obstructive sleep apnoea: Effect on peripheral nerve function. J Neurol Neurosurg Psychiatry 2007;78:295-7.

18. Song D, Fang G, Greenberg H, Liu SF. Chronic intermittent hypoxia exposure-induced atherosclerosis: A brief review. Immunol Res 2015;63:121-30
19. Deng F, Wang S, Xu R, Yu W, Wang X, Zhang L. Endothelial microvesicles in hypoxic hypoxia disease. I Cell Mol Med 2018;22:3708-18.

20. Frolkis VV, Tanin SA, Gorban YN. Age-related changes in axonal transport. Exp Gerontol 1997;32:441-50.

21. Malik RA, Veves A, Masson EA, Sharma AK, Ah-See AK, Schady W, Lye $\mathrm{RH}$, Boulton AJM. Endoneurial capillary abnormalities in mild human diabetic neuropathy. J Neurol Neurosurg Psychiatry 1992;55:557-61.

22. lida H, Schmelzer JD, Schmeihel AM, Wang Y, Low PA. Peripheral nerve ischemia: Reperfusion injury and fiber degeneration. Exp Neurol 2003;184:997-1002.

23. Wang Y, Schmelzer JD, Schmeichel A, lida H, Low PA. Ischemiareperfusion injury of peripheral nerve in experimental diabetic neuropathy. J Neurol Sci 2004;227:101-7.

24. Bondy SC, Le Bel CP. The relationship between excitotoxicity and oxidative stress in the central nervous system. Free Radic Biol Med 1993; 14:633-42.

25. Ludolph AC, Riepe M, Ulrich K. Excitotoxicity, energy metabolism and neurodegeneration. J Inherit Metab Dis 1993;16:716-23.

26. Hampton KK, Alani SM, Wilson JI, Price DE. Resistance to ischaemic conduction failure in chronic hypoxemia and diabetes. J Neurol Neurosurg Psychiatry 1989;52:1303-5. 